\title{
Hydrodynamics and seed dispersal in the lower Amazon
}

\author{
Alan Cavalcanti da Cunha ${ }^{1}$ (D) $\mid$ Karen Mustin $^{2}$ | Eldo Silva dos Santos ${ }^{1}$ | Éwerton \\ Wânderson Gonçalves dos Santos ${ }^{1}$ | Marcelino Carneiro Guedes ${ }^{2}$ | Helenilza Ferreira \\ Albuquerque Cunha ${ }^{1}$ | Paulo Cesar Colonna Rosman ${ }^{3}$ | Leonel da Silveira Lobo Sternberg ${ }^{4}$
}

\author{
${ }^{1}$ Departamento de Meio Ambiente e \\ Desenvolvimento, Universidade Federal do \\ Amapá (UNIFAP), Macapá, Brazil \\ ${ }^{2}$ Empresa Brasileira de Pesquisa \\ Agropecuária - Embrapa Amapá, Macapá, \\ Brazil \\ ${ }^{3}$ COPPE - Departamento de Engenharia \\ Costeira \& Oceanográfica, Universidade \\ Federal do Rio de Janeiro (UFRJ), Rio de \\ Janeiro, Brazil \\ ${ }^{4}$ Department of Biology, University of \\ Miami (UM), Miami, FL, U.S.A.
}

\section{Correspondence}

Alan Cavalcanti da Cunha, Departamento de Meio Ambiente e Desenvolvimento, Universidade Federal do Amapá (UNIFAP), Rodovia JK, km 2. Jardim Marco Zero. CEP: 68900-000 Macapá, Brazil.

Email: alancunha12@gmail.com

\section{Funding information}

Conselho Nacional de Desenvolvimento Científico e Tecnológico (CNPq), Grant/ Award Number: 303715/2015-4 and 475614/2012-7; Empresa Brasileira de Pesquisa Agropecuária; Financiadora de Estudos e Projetos; Instituto Nacional de Pesquisas da Amazônia; TROCAS: Net Ecosystem Exchange of Lower Amazon, Grant/Award Number: 2012/51187-0; Universidade Federal do Amapá

\begin{abstract}
1. The transport of seeds by water, i.e. hydrochory, is a key mechanism of long-distance dispersal constrained by the attributes of the seed and hydrodynamics. In the freshwater Amazon estuary, river hydrodynamics are influenced by seasonal changes in precipitation and tidal cycles. It is not known to what extent a hydrodynamic model may be able to predict seed dispersal.
\end{abstract}

2. Here we parameterised a simulation model (SisBaHia) to estimate maximum seed dispersal distances per tidal cycle, which were then compared with data from in situ seed dispersal experiments. The study was conducted along a 27-km stretch of a tributary of the Amazon estuary, using the seeds of a widely distributed riparian tree-Carapa guianensis (Meliaceae).

3. Based on the simulation model, maximum potential seed dispersal distance was higher in the rainy season (c. $8.7 \mathrm{~km}$ ) when compared with the dry season $(5.6 \mathrm{~km})$, for one tidal cycle $(12 \mathrm{hr})$. The seeds of $C$. guianensis were dispersed further during the ebb than flood tide during the rainy season, the period of seed dispersal. Average dispersal distances observed in seed dispersal experiments conducted during the rainy season, and those predicted by SisBaHia for the same period were within the same order of magnitude.

4. The results of this study confirm that the period of higher precipitation provides favourable hydrological conditions for hydrochory in the Amazon river-estuary complex. The fact that the time taken for the tide to fall is longer in relation to the time taken for it to rise also favours the arrival of the seeds in the main channel of the Amazon, thereby increasing the probability of long-distance dispersal events.

KEYWORDS

Carapa guianensis, long-distance dispersal, modelling, simulation, tidal river

\section{1 | INTRODUCTION}

Seed dispersal is one of the key processes determining the spatial structure of plant populations, contributing to the processes of competition and coexistence, and gene flow (Howe \& Smallwood, 1982; Nathan \& Muller-Landau, 2000; Ouborg, Piquot, \& Van Groenendael,
1999). While most commonly reported, it is not only mean dispersal distances but rather the entire distribution of dispersal distances (dispersal kernel) that are important in determining range expansion rates, recruitment patterns, genetic structure, meta-population dynamics and ultimately community diversity (Cain, Milligan, \& Strand, 2000; Levin, Muller-Landau, Nathan, \& Chave, 2003; Ouborg 
et al., 1999; Abreu, Guedes, \& Lira Guedes, 2014). However, characterising the complete dispersal kernel is complicated, as long-distance dispersal events are inherently difficult to measure (Cain et al., 2000).

One mechanism known to be important in long-distance dispersal in riparian and wetland systems is hydrochory, in which seeds are transported on or in flowing water (Cain et al., 2000; Nilsson, Brown, Jansson, \& Merritt, 2010). This is particularly complicated to quantify in large rivers, such as the Amazon River basin discharging approximately $20 \%$ of the world's fresh water (Ward et al., 2016; Salati, \& Vose, 1984). Seeds are transported in fluvial systems in one of three phases, representing the main hydrological forces: (1) surface transport (with the dispersion of seeds occurring on the surface of the water), (2) within the flow and (3) incorporated in the bed load (Carthey, Fryirs, Ralph, Bu, \& Leishman, 2016). Hydrochory influences not only the diversity, structure and composition of riparian vegetation but also geomorphological processes such as stabilisation of river banks and the succession of geomorphic forms such as bars and benches into floodplain, further affecting patterns of vegetation colonisation on bars, benches and islands within rivers (Carthey et al., 2016). Hydrochory also promote sediment cohesion, sediment deposition and trapping of additional hydrochores, forming a feedback loop of ongoing adjustment between vegetation patterns and fluvial geomorphology, which is strongly influenced by the dynamics of hydrochorous propagule dispersal in rivers (Carthey et al., 2016).

A large proportion of riparian and wetland plant species display hydrochory, although usually in combination with other dispersal vectors such as wind (anemochory), animals (zoochory) and the plant itself (autochory) (Levin et al., 2003; Nilsson et al., 2010). Dispersal distance by hydrochory in rivers is influenced by both: intrinsic factors such as size, shape, density and longevity of the seed; and extrinsic factors such as the size and morphology of the river channel, timing and magnitude of peak river flow (Kubitzki \& Ziburski, 1994; Merritt \& Wohl, 2002; Nilsson et al., 2010). For example, seeds with traits that increase flotation and which show dormancy have a greater probability of reaching the best sites for germination such as bare, waterlogged soils exposed by rainy season floods (Boedeltje, Bakker, Brinke, Van Groenendael, \& Soesbergen, 2004). It has been suggested that hydrochory may be the most important factor for maintaining species diversity in riparian habitats (Nilsson et al., 2010). However, most studies of how far propagules can spread by hydrochory come from marine systems, and the tail of the dispersal kernel is much less well-studied for rivers (Nilsson et al., 2010).

In the Amazon, riverine wetlands can be broadly separated into those $>850 \mathrm{~km}$ from the river mouth, which flood seasonally, and those between c. $750 \mathrm{~km}$ upstream and the river mouth, which flood both seasonally and tidally (Instituto Brasileiro de Geografia e Estatística, 1977, National Geospatial-Intelligence Agency, 2014; Prance, 1979, Ward et al., 2016). As such, in the lower reaches of the Amazon river-estuary complex, twice daily tidal inundations disperse seeds up and downstream, in contrast to higher reaches of the riverestuary complex, where hydrochory is a unidirectional process, with seeds being carried downstream with river flow (Cunha et al., 2013) The role of tidal inundations as vectors of seed dispersal has received relatively little attention. However, there is evidence from the Amazon river-estuary complex that the proportion of seeds dispersed is greatest when water depths are greatest, at new and full moons (Moegenburg, 2002).

One way to characterise species dispersal kernels is to parameterise mathematical and/or simulation models to predict long-distance dispersal and seed dispersion patterns under different hydrodynamic conditions (Cain et al., 2000; Levin et al., 2003). The main objective of this study was therefore to investigate and quantify the spatiotemporal variation in fundamental hydrodynamic flow parameters at different seasons in a river-estuary complex of the lower Amazon, and to evaluate the usefulness of these parameters for hydrochory. More specifically, we aimed to (1) characterise empirically, and using simulation models, the hydrodynamic conditions of a $27-\mathrm{km}$ stretch of river channel, extending from the confluence with the main Amazon River and (2) use the calibrated simulation model to predict the maximum potential seed dispersal distances during semi-diurnal tidal cycles and compare it with an actual seed dispersal experiment.

\section{2 | METHODS}

\section{1 | Study area}

The study was conducted along a sharply winding 27-km stretch of the Maracá River, a typical tributary of the lower Amazon river-estuary complex (Souza, Cunha, Junior, \& Pinheiro, 2011). The Maracá River originates in the south-west of the state of Amapá, Brazil (Figure $1 \mathrm{a}, \mathrm{c})$ and flows into the Amazon River at $0^{\circ} 25^{\prime} 07.82^{\prime \prime} \mathrm{S}$ and $51^{\circ} 26^{\prime} 07.64^{\prime \prime} \mathrm{W}$ (Figure 1c, d). The study area is c. $250 \mathrm{~km}$ from the Atlantic Ocean, and while the tide influences water height and flow direction, it is still considered as completely fluvial, being well upstream from any saltwater influence (Ward et al., 2016).

The region has a hot and humid tropical monsoon climate, with an average annual temperature of $27.7^{\circ} \mathrm{C}$ (Instituto Nacional de Meteorologia, 2015). Average annual rainfall is $2,423 \mathrm{~mm}$, irregularly distributed throughout the year, with highest rainfall between January and June (Instituto Nacional de Meteorologia, 2015). River water levels are influenced by this seasonal variation in rainfall, and by semi-diurnal tides, rising and falling twice daily, with maximum amplitudes reached at full and new moons during the rainy season, when river levels rise by up to $4 \mathrm{~m}$ (Bastos, 2010; Cunha et al., 2013; Galo, 2004; Santos, 2012). River flow is characterised by turbulent processes, inversion of current and recirculation, typical of estuarine systems, and these processes influence the maintenance of the wetlands associated with the river.

\section{2 | Data collection and processing}

Data on hydrological parameters were collected during three field trips in September 2012 (dry season, neap tide), January 2013 (transition between the dry and rainy season, neap tide) and May 2013 (rainy season, spring tide). These periods were chosen in order to detect the full variation in the average tidal amplitude and current 
(a)

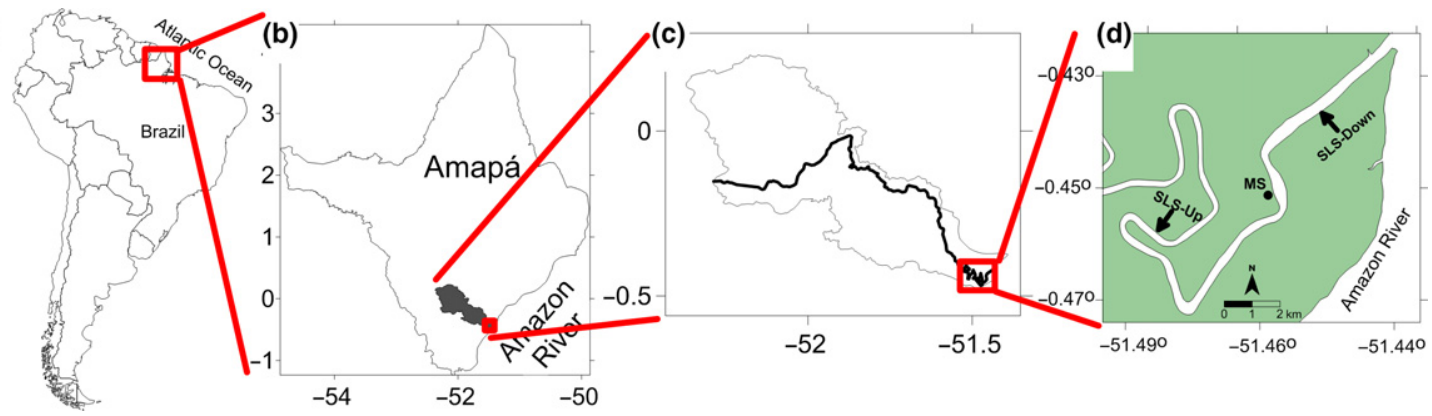

FIGURE 1 Location of (a) the state of Amapá within Brazil and South America, (b) the study site within the state of Amapá and (c) the catchment within the municipality of Mazagão (c. $250 \mathrm{~km}$ from Atlantic Ocean). Panel (d) shows a representation of the spatial grid of finite elements across which all input variables were discretised. The dot marked "MS" shows the location where liquid discharge, velocity and water level measurements were made. The two sites marked "SLS- (Up or Down)" show the two locations from which seeds were launched during the seed dispersal experiment

velocity during the hydrological cycle in the study area. Seed dispersal experiments were carried out only in May 2013 to provide data to compare modelled estimates and measured maximum dispersal distances during both ebb and flow tides, because this period is considered to be the most favourable for hydrochory in this region.

\section{3 | Measurement of hydrological parameters}

In order to generate a 3D map of the river channel to be used in later modelling, measurements of river bathymetry were made with an acoustic Doppler profiler (ADP SonTek River Surveyor M9) installed on the side of a motor boat, and consisting of four $3 \mathrm{MHz}$ transducers and four $1 \mathrm{MHz}$ transducers that were submerged $0.4 \mathrm{~m}$ under water. The river depth was mapped with measurements made along a zigzag transect extending along $27 \mathrm{~km}$ of the river (Figure 1d). The data were transmitted via Bluetooth ${ }^{\mathrm{TM}}$ connection to a mobile phone using the River Surveyor Live Mobile software associated with the ADP, and a GPS (GARMIN 76CSx) was used to register the coordinates of the measurements. Current velocity $(\mathrm{Vt})$ was also measured, using the ADP, every 10 min crossing the river back and forth, perpendicular to the current at a fixed point for the duration of one complete semi-diurnal tide cycle (c. $12.5 \mathrm{hr}$ ) per sampling period (Figure 1, "MS" = "measurements site").

The parameters of river flow may be approximated by a 3D model with a single average depth in shallow rivers. The resulting model is numerically more efficient. In this study, the sampled $27-\mathrm{km}$ stretch of river is wide in relation to its depth (average depth $=6.5 \mathrm{~m}$, average width $=123 \mathrm{~m}$, aspect ratio c. 20), and as such is considered a shallow water river. Given that the study area is well upstream of any saltwater influence, our approximation of river flow can be considered a good representation of the true $3 \mathrm{D}$ phenomenon. Using the bathymetric survey data, representations of the $27 \mathrm{~km}$ river section were generated by kriging over a grid of 598 finite elements (Figure 1d) using the software Google Earth ${ }^{\circledR}$, version 6.1.0.5001 (Google, Inc.); Surfer $^{\circledR}$, version 10.1.561, 64-bits (Golden Software, Inc.) and Argus $\mathrm{ONE}^{\circledR}$, version 4.2.0q (Argus Holdings Ltda.).

For each sampling period, the discharge $Q\left(\mathrm{~m}^{3} / \mathrm{s}\right)$, or volume of water moving down the river per unit time, was calculated based on the measurements of current velocity $(\mathrm{m} / \mathrm{s})$, integrated for the area $(A=z . y)$ of the river profile at each crossing of the river (which varies temporally in the tidal cycle). The continuity equation of the volume control (Figure 2) for the permanent shaping bathymetry period, i.e. $z=h(x, y)$, was, according to Rosman (2016) as follows:

$$
\frac{\partial \zeta}{\partial t}+\frac{\partial U H}{\partial x}+\frac{\partial \mathrm{VH}}{\partial y}=\underbrace{q_{\mathrm{P}}-q_{\mathrm{E}} \pm q_{\mathrm{I}}}_{\sum q}
$$

where $\zeta$ is the elevation of the water surface; $U$ is the velocity on the $x$-axis; $V$ is the velocity on the $y$ axis; $H$ is the instant depth $(m)$; $q_{\mathrm{P}}$ represents effects due to precipitation; $q_{\mathrm{E}}$ represents effects due to evaporation and $q_{1}$ represents effects due to infiltration. The amount of movement along the $x$ - and $y$-axes was calculated by:

$$
\begin{aligned}
\frac{\partial U}{\partial t}+U \frac{\partial U}{\partial x}+V \frac{\partial U}{\partial y}= & -g \frac{\partial \zeta}{\partial x}-\frac{g H}{2 \rho_{o}} \frac{\partial \rho}{\partial x}+\frac{1}{\rho_{o} H}\left(\frac{\partial\left(H \bar{\tau}_{x x}\right.}{\partial x}+\frac{\partial\left(H \bar{\tau}_{x y}\right)}{\partial y}\right) \\
& +\frac{1}{\rho_{o} H}\left(\tau_{x}^{S}-\tau_{x}^{B}\right)+2 \Phi \operatorname{sen} \theta_{V}-\frac{U}{H} \sum q
\end{aligned}
$$

$$
\begin{aligned}
\frac{\partial V}{\partial t}+U \frac{\partial V}{\partial x}+V \frac{\partial V}{\partial y}= & -g \frac{\partial \zeta}{\partial y}-\frac{g H}{2 \rho_{o}} \frac{\partial \rho}{\partial y}+\frac{1}{\rho_{o} H}\left(\frac{\partial\left(H \bar{\tau}_{x y}\right.}{\partial x}+\frac{\partial\left(H \bar{\tau}_{y y}\right)}{\partial y}\right) \\
& +\frac{1}{\rho_{o} H}\left(\tau_{y}^{S}-\tau_{y}^{\mathrm{B}}\right)+2 \Phi \operatorname{sen} \theta_{u}-\frac{V}{H} \sum q
\end{aligned}
$$



FIGURE 2 Graphical representation of the 3D coordinate system model. $\mathrm{RL}$ is the Reference Level, $U_{i}$ is the integrated speed vertically, $u_{i}$ is a generic speed of the $3 \mathrm{D}$ model and varies with depth, $\zeta$ is the elevation of the free surface of the water, $h$ is the depth obtained by bathymetry and $H$ is the instantaneous depth $(H=\zeta+h)$-adapted from Rosman (2016) 
where $U$ is the velocity in $x$-axis $(\mathrm{m} / \mathrm{s}) ; V$ is the velocity on the $y$ axis $(\mathrm{m} / \mathrm{s}) ; \zeta$ is the elevation of the water surface $(\mathrm{m}) ; H$ is the instant depth $(\mathrm{m}) ; \rho_{o}$ is the density of water averaged vertically $\left(\mathrm{kg} / \mathrm{m}^{3}\right) ; \rho$ is the constant density reference $\left(\mathrm{kg} / \mathrm{m}^{3}\right) ; g$ is the acceleration due to gravity $\left(\mathrm{m} / \mathrm{s}^{2}\right) ; \bar{\tau}_{i j}$ is the tensor of turbulent stresses $\left(\mathrm{kg} \mathrm{m}^{-1} \mathrm{~s}^{-2}\right)$ and $i$ and $j$ represent two dimensions or area; $\tau_{i}^{s}$ is the shear stress at the free surface $\left(\mathrm{kg} \mathrm{m}^{-1} \mathrm{~s}^{-2}\right) ; \Phi$ is the angular speed of Earth's rotation $(\mathrm{m} / \mathrm{m}) ; \theta$ is the latitude angle $(\mathrm{m} / \mathrm{m})$; and $\Sigma q$ is the sum of the effects due to precipitation, evaporation and infiltration $\left(\mathrm{m}^{3} \mathrm{~s}^{-1} \mathrm{~m}^{-2}\right)$.

The experimental bulk discharge was measured directly using the ADP (Table 1). However, the partial discharges at the top, bottom and banks of the river were estimated indirectly by extrapolation with the ADP software itself using an exponential function (Mueller, Wagner, Rehmel, Oberg, \& Rainville, 2009). The total flow rate was used in the hydrodynamic analysis, which is the result of the sum of all flows: experimental, top, bottom and margins.

Water level data were collected every 5 min throughout each study period, using Hobo pressure sensors (water level logger U20) attached to wooden posts and submerged at a minimum depth of $1 \mathrm{~m}$ at the same location where velocity was sampled (Figure 1d, "MS"). Water pressure data were converted to water level above the sensor using the relationship between the last registration of water pressure and the water level at the time of data upload, which was verified using the wooden ruler upon which the sensors were installed. The calculation was made automatically by the pressure sensor software (Onset, 2016) using the pressure readings every 5 min during the collection period, providing ultimately water level readings every $5 \mathrm{~min}$. These data were compared with water level data from the permanent hydrological monitoring station at the Port of Santana (c. $30 \mathrm{~km}$ downstream in the Amazon River-data not shown) Agência Nacional de Águas (2016).

\subsection{Seed dispersal experiment}

In order to evaluate seed dispersal behaviour and compare average distances travelled with those predicted by the simulation model, in

TABLE 1 Experimental measurements of liquid discharge and average velocities throughout the hydrological (seasonal) periods and semi-diurnal tide cycles in the Maracá River at the "MS" section (Figure 1)

\begin{tabular}{|c|c|c|c|}
\hline & $\begin{array}{l}\text { September } \\
2012\end{array}$ & $\begin{array}{l}\text { January } \\
2013\end{array}$ & May 2013 \\
\hline $\begin{array}{l}\text { Maximum flow } \\
\text { rate }\left(+Q \mathrm{~m}^{3} / \mathrm{s}\right)^{\mathrm{a}}\end{array}$ & 734.24 & 872.06 & 1,025 \\
\hline $\begin{array}{l}\text { Minimum flow } \\
\text { rate }\left(-Q \mathrm{~m}^{3} / \mathrm{s}\right)^{b}\end{array}$ & $-1,464.89$ & $-1,185.98$ & $-1,713.33$ \\
\hline $\begin{array}{l}\text { Net flow rate } \\
\left(Q \mathrm{~m}^{3} / \mathrm{s}\right)^{\mathrm{c}}\end{array}$ & -60.66 & 1.58 & 78.13 \\
\hline $\begin{array}{l}\text { Average velocity } \\
(U \pm S D \mathrm{~m} / \mathrm{s})\end{array}$ & $0.42 \pm 0.23$ & $0.51 \pm 0.24$ & $0.56 \pm 0.23$ \\
\hline
\end{tabular}

a Maximum flow rate $\left(+Q \mathrm{~m}^{3} / \mathrm{s}\right)=$ ebb tide.

${ }^{\mathrm{b}}$ Minimum flow rate $\left(-Q \mathrm{~m}^{3} / \mathrm{s}\right)=$ flood tide.

${ }^{c}$ Net flow rate: difference between average input rate and output rate during a tidal cycle.
May 2013, two seed dispersal experiments were conducted (ebb and flood tides). The conditions in this sampling period (rainy season, spring tide) represent the most favourable for seed dispersal. In the study region, May is also the period of highest seed production and main dispersal period for Carapa guianensis, the species used in the experiments (Cunha et al., 2013; Dantas, Lira-Guedes, Mustin, Aparício, \& Guedes, (2016)). In both experiments, the total maximum dispersal distance was evaluated during one full tidal cycle.

In the first experiment, 500 C. guianensis seeds were launched from a single location (Figure 3a-c, "SLS-Up" = "upstream launching site"), approximately $12 \mathrm{~km}$ upstream from the river mouth, at the beginning of the ebb tide. In the second experiment, 500 andiroba seeds were launched from a single location (Figure 3d, "SLSDown" = "downstream launching site"), approximately $2.3 \mathrm{~km}$ from the river mouth, at the beginning of flood tide. In both experiments, the seeds originated from the 2012 harvest period (March to May) which is when most seeds mature and would then be dispersed under natural conditions (Dantas et al., 2016). The seeds were sorted and damaged and immature seeds were discarded, such that only mature, fully formed seeds were used. The remaining seeds were then submerged in water for $24 \mathrm{hr}$ to kill off larvae of a parasitic moth that infects this species, after which time, the seeds were dried and stored for use. Although such dried seeds last for several years without influencing buoyancy, in this case, the seeds were c. 12 months old. Drying of the seeds post-collection is an important step as undried seeds could begin to germinate, reducing buoyancy and influencing the experimental results. The 500 seeds launched at the beginning of the ebb tide were painted yellow, and the 500 seeds launched at the beginning of the flood tide were painted white, in order to facilitate the visual tracking of the plumes of seeds and to evaluate dispersal behaviour.

Visual tracking of the seeds was carried out from two boats that accompanied the plumes throughout the experiment, as well as from a fixed location at the monitoring point (MS) as a reference (Figure 1d). The main boat followed the seed kernel plume (from a distance of c. $30 \mathrm{~m}$ so as not to induce turbulence and influence seed dispersal). The second boat recorded GPS locations of the plume tails every hour using a Garmin 76CSx. With this simple procedure, it was possible to approximate the average, minimum and maximum dispersal distances of the seeds under natural conditions, and these values were then related to those obtained in the model simulations.

Carapa guianensis (Andiroba) is a tree species that occurs throughout the Amazon Basin (Kenfack, 2011) and dependent upon long-distance dispersal events. In the estuarine várzeas of the River Amazon, $C$. guianensis flowers in the period of lowest precipitation and disperses its seeds during the period of highest precipitation, when the variation in water level of the main channel of the Amazon is greatest, and its tributaries are subject to the effects of the tides (Dantas et al., (2016)). Seeds of this species float on the surface of the water and are highly adapted to hydrochory (Scarano et al., 2003). Close to $100 \%$ of seeds continue to float up to 10 days after entering the water, and around $40 \%$ after 55 days (Lopez, 2001). Carapa guianensis seeds have been found as an occasional 

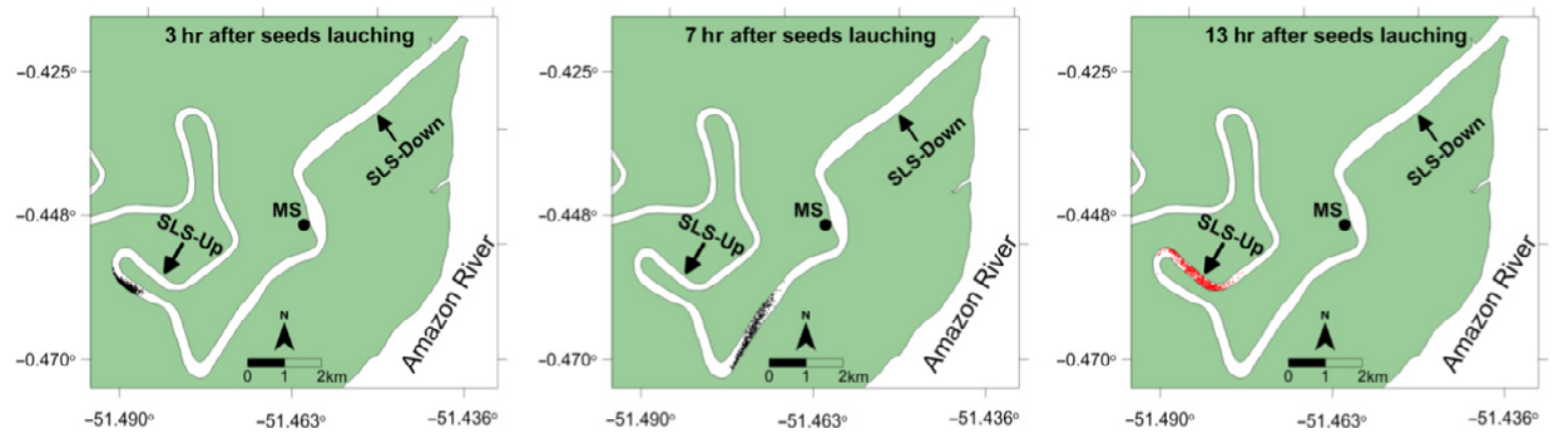

(a) September-2012 - Ebb/Flood Tides. Launch in SLS-Up.
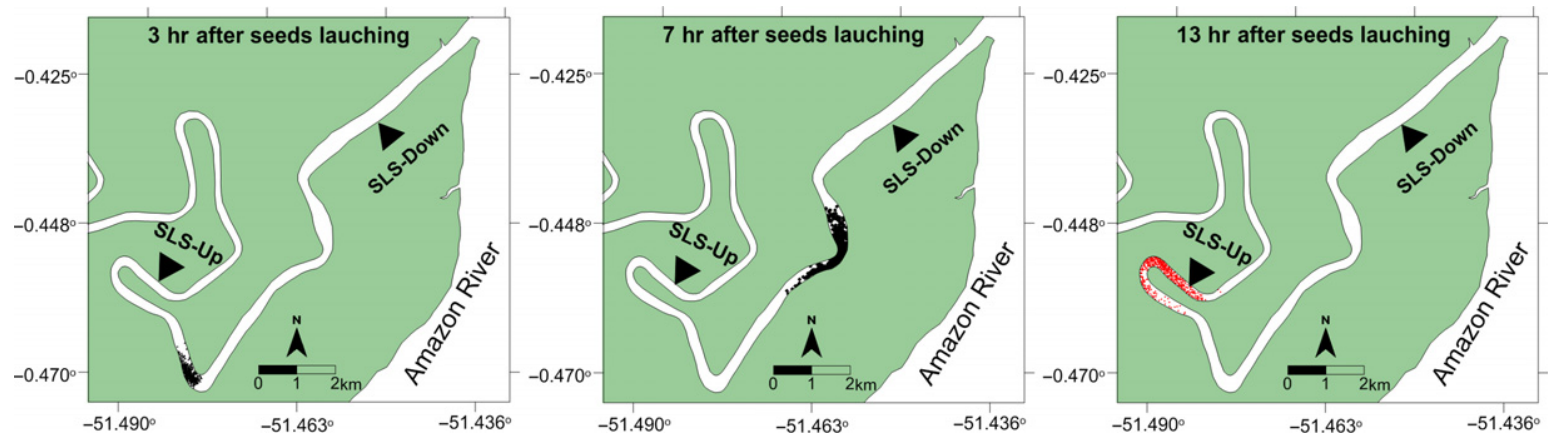

(b) January-2013 - Ebb/Flood Tides. Launch in SLS-Up.


(c) May-2013 - Ebb/Flood Tides. Launch in SLS-Up compared with experimental dispersal (Table 2).


(d) May-2013 - Ebb/Flood Tide. Launch in SLS-Down compared with experimental dispersal (Table 2)

FIGURE 3 The simulated seed dispersal plumes in (a) the September 2012 ebb tide simulation, (b) the January 2013 ebb tide simulation, (c) the May 2013 ebb tide simulation and (d) the May 2013 flood tide simulation. The two sites marked "SLS- (Up or Down)" show the two locations from which seeds were launched during the seed dispersal simulations. Black and red colours are used to distinguish the positions of the seeds before and after the switching of the tide 
component of debris deposited on the Atlantic beach at Tortuguero and Corcovado National Park on the Pacific (Costa Rica) and especially near the mouths of water courses, showing that the seeds float until they rot (Mchargue \& Hartshorn, 1983), and suggesting that they could even be tolerant to salinity.

\section{5 | Modelling hydrochory}

All modelling was carried out in SisBaHia (http://www.sisbahia.c oppe.ufrj.br/), an open access modelling platform developed by the Fundação Coppetec, Universidade Federal do Rio de Janeiro (Rosman, 2016). SisBaHia is composed of a FIST (Filtered In Space and Time) hydrodynamic model optimised for natural bodies of water, models of water quality, Eulerian and Langrangian transport models, and wave and tidal models (Rosman, 2016). It has been widely used in Brazil to, for example: model future changes in astronomical tides, assess the environmental impacts of sewage discharge and study hydrodynamic phenomena (e.g. Barbedo, Miguez, van der Horst, \& Marins, 2014; Cunha, Scudelari, Gonçalves, \& Mercuri, 2011; Cunha, Scudelari, \& Rosman, 2015; Leite, Dias, Carvalho, \& Klein, 2011; Santos, Lima Saraiva, Pereira, Nogueira, \& Silva, 2015).

Here, the FIST3D model (3D version of FIST hydrodynamic model) which resolves the complete Navier-Stokes equations (Equations 1-3) with approximation for shallow water equations (one average depth, $H$ ), the tidal prediction tool and an advective-diffusive Lagrangian transport model were used to model hydrochory.

\section{6 | Input data and model parameterisation}

Input data were spatially discretised over a grid of 598 finite elements. The parameters which needed to be defined across the grid for the hydrodynamic model were as follows: amplitude of riverbed roughness, inclination of the river banks and flow conditions. The clay bed of the river was more-or-less smooth; hence, amplitude of riverbed roughness was considered to be constant and equal to $0.02 \mathrm{~m}$ in all elements of the grid. For elements along the river margins, a normal flow condition was assumed, which implied the banks of the river are smooth. This assumption was made as it was not computationally possible to include rough river banks or other floating debris. For elements at the mouth of the river, an open border boundary condition was imposed, which allows for flow in and out, as is the case in a tidal channel. A sensitivity analysis was performed, varying parameters defining riverbed roughness and inclination of the river banks within realistic ranges. Error estimates were checked for adherence to model limitations, and to evaluate model performance, using the root-mean-square error, overall standard deviation of errors and coefficient of correlation between experimental and modelled data $(R)$.

To model the tidal amplitudes of the Maracá River, tidal data were collected at the Port of Santana (FEMAR, 2013), c. $30 \mathrm{~km}$ from the mouth of the Maracá River. Based on these data, SisBaHiA ${ }^{\circledR}$ 's standard turbulent model $(k-\varepsilon)$ elaborated tidal oscillation curves for the Maracá River, applying a time lag and reduction in amplitude according to the dissipation of energy as the tidal wave is dampened as it moves upstream (GALO, 2004). The relationship between these predicted tidal oscillations and water level data collected in the Maracá River was tested using Wilcoxon's nonparametric statistical test $(p<.05)$.

Regarding the physical parameterisation of the seeds in the SisBaHiA (Rosman, 2016), there are several ways to input biological characteristics of the seed in question. For example: (1) the location of the seed dispersal; (2) the timing of the dispersal; and (3) seeds can have different characteristics (such as size and density), specifying a settling velocity conditioned by the hydrodynamics through the speed limit or the settling at the bottom. The SisBaHia can include seed deposition when the values are below a specified limit (e.g. as specified by Lopez, 2001). The SisBaHia can also use "absorption factors" in the margins, simulating effects of marginal entrapment of seeds. Here, we hypothesise that all seeds presented constant buoyancy and there were no losses of seeds at the margins and bottom of the channel.

However, despite the potential loss of seeds during the field experiment, this study was not intended to approximate the number of seeds transported but rather the general dispersion of seeds (distances).

\section{7 | Simulations of hydrochorous seed dispersal (Lagrangian model)}

Dispersal of seeds on the water surface was simulated based on the modelled hydrodynamic and tidal effects, and using the Lagrangian numerical model. The Lagrangian model was selected because it can be efficiently applied to problems with point sources (Rosman, 2016). Here, the instantaneous launching of a certain quantity of seeds from a point c. $12 \mathrm{~km}$ (SLS-Up) from the river mouth and a point c. $2.3 \mathrm{~km}$ (SLS-Down) from the river mouth was simulated (Figure $3 a-d)$. In this type of model, the position of any seed in the next time step of the simulation is determined by a Taylor expansion based on the previous or initial time step.

All simulations were carried out for a duration between 12 and $72 \mathrm{hr}$, with a time step of $60 \mathrm{~s}$, which was considered sufficient to visualise the process of hydrochory in up to six consecutive semidiurnal tides (through Figure 4a-d show just one semi-diurnal cycle for clarity of comparison). In all cases, all 500 seeds were assumed to be launched simultaneously. The average distances dispersed by seeds in these simulations were compared with the observed average distances from the seed dispersal experiments (Figure $3 c-d$ ).

\section{RESULTS}

\subsection{Empirical and model-based characterisations of river channel hydrodynamics}

The time taken for the tide to rise was shorter in the dry season (September 2012, $4.4 \mathrm{hr}$ ), and was longer during the transition (January 2013, 5.39 hr) and rainy (May 2013, 5 hr) seasons. However, 

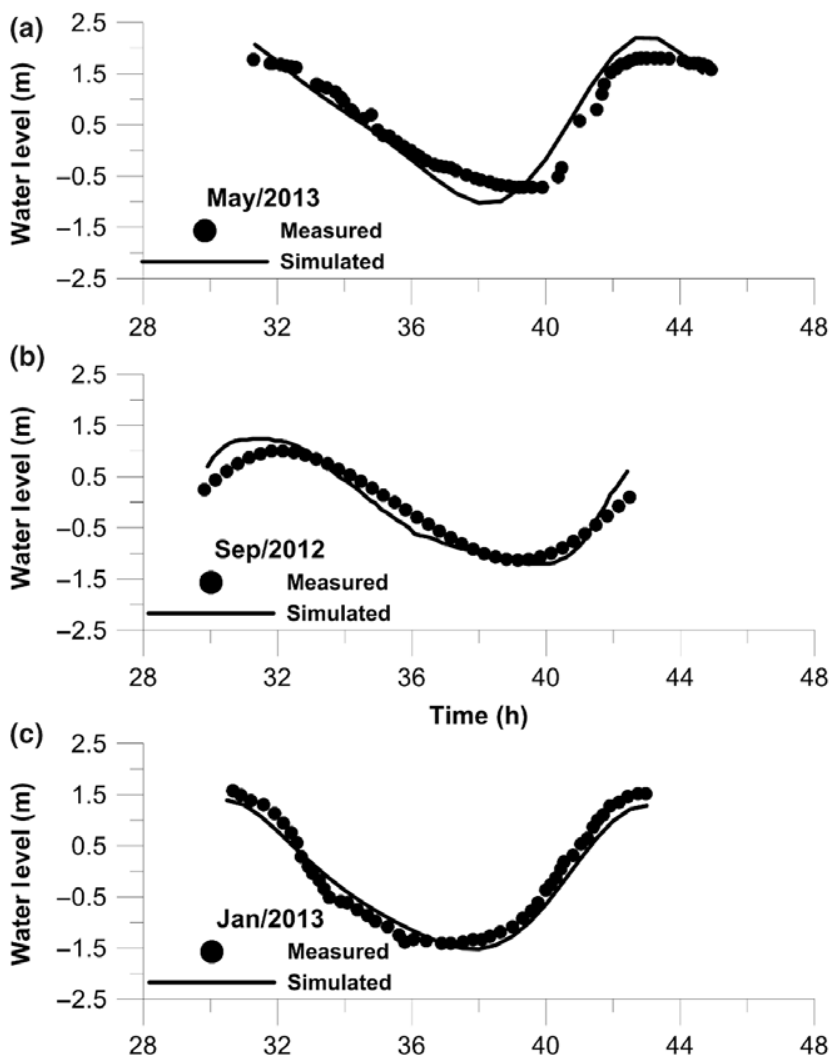

(d)

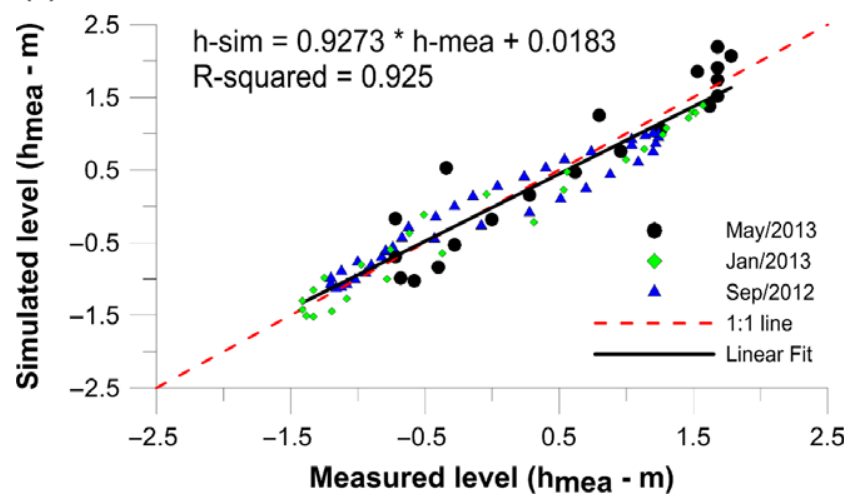

FIGURE 4 Observed and simulated (SisBaHia) tidal levels during (a) 28 May 2013-30 May 2013 (rainy season), (b) 9 September 2012 (dry season), (c) 1 January 2013-3 January 2013 (transition period between dry and rainy seasons) and panel (d) shows the observed and predicted tidal level data for all three sampling periods together

the time taken for the tide to fall was longer in the dry season (September 2012, $7.9 \mathrm{hr}$ ) than the transition (January 2013, $7.33 \mathrm{hr}$ ) or rainy (May 2013, 7.5 hr) seasons. Tidal peaks were higher and tidal amplitude greater during the rainy season (May). Measured maximum flow rates, net flow rates and average river velocities increased from the dry to rainy seasons (Table 1). Measured minimum flow rates were more variable, being lowest in the transition period, and highest during the rainy season (Figure 3).

The estimated tidal amplitudes produced by SisBaHia were good approximations of the observed tidal amplitudes in all three sampling periods (Figure 4), with an average $3 \mathrm{~cm}$ difference between observed and predicted values, which was considered to be an acceptable and relatively small error. Data were only available for one tidal cycle in September 2012 due to a malfunction in the pressure sensor used as a tidal gauge. However, in this and both other sampling periods, correlations between predicted and observed tidal levels were strongly correlated $(R=.95$ [May 2013]; $R=.97$ [September 2012]; $R=.99$ [January 2013] and $R=.96$ all three sampling periods together). The model was, therefore, considered to be calibrated to represent the hydrodynamics of the river flow, which allowed us to couple it with the Lagrangian model to simulate hydrochory.

\subsection{Comparison of modelled and observed seed dispersal distances}

Average dispersal distances observed in the seed dispersal experiments and those predicted by SisBaHia were within the same order of magnitude (Table 2).

Development of the seed plume, after initialisation of the simulation can also be seen in the Figure $3 a-d$. Comparing the three periods, simulated maximum potential dispersal distance during the ebb tide was longest in the rainy season (May 2013), reaching approximately $8.7 \mathrm{~km}$ downstream from the release section (Figure 3, Table 2), cf. $5.3 \mathrm{~km}$ in the dry season and $8.2 \mathrm{~km}$ in the transition period. Comparing the ebb and flood tides, only in the rainy season, seeds were dispersed further during the ebb than flood tide, with the latter reaching up to $7.3 \mathrm{~km}$ upstream from the release section (Figure 3c-d).

Experimental seed dispersal data showed that during the ebb tide in May 2013, seeds reached the observation section MS (Figure $3 \mathrm{c}, \mathrm{d}$ ), about 6:30 and 11:00 hr after their launch. During the flood tide, the time taken was between 1:40 and 10:30 hr. In both cases, the corresponding SisBaHia simulated distances are similar to the experimental ones (errors between $4.8 \%$ and 13.0\%) (Table 2).

However, during the field experiments, there was a $30 \%-40 \%$ loss of the seeds in the margins in the upstream stretch (c. $50 \mathrm{~m}$

TAB LE 2 Experimental and simulated dispersal distances along the Maracá River during one semi-diurnal tidal cycle (only in May 2013 period)

\begin{tabular}{|c|c|c|c|}
\hline $\begin{array}{l}\text { Experimental kernel distance }{ }^{a} \\
\text { Ebb/flood tides }\left(x_{\min }\left|x_{\text {aver }}\right| x_{\max }\right)\end{array}$ & $\begin{array}{l}\text { Simulated kernel distance } \\
\text { Ebb/flood tides }\left(\boldsymbol{x}_{\min }\left|\boldsymbol{x}_{\text {aver }}\right| \boldsymbol{x}_{\max }\right)\end{array}$ & $\begin{array}{l}\text { Relative errors } \\
E=\left|\left(\frac{\text { Exp-Sim }}{\text { Exp }}\right)\right| 100 \% \\
\text { Ebb/flood tides }\left(x_{\min }\left|x_{\text {aver }}\right| x_{\text {max }}\right)\end{array}$ & $\begin{array}{l}\text { Absolute distance errors } \\
E_{\mathrm{Abs}}=|\operatorname{Exp}-\operatorname{Sim}|(\mathrm{km}) \\
\text { Ebb/flood tides }\left(\boldsymbol{x}_{\min }\left|\boldsymbol{x}_{\text {aver }}\right| \boldsymbol{x}_{\max }\right)\end{array}$ \\
\hline 6.5 | 7.5 | 8.4 & 5.7 | 6.9 | 8.0 & $12.3|8.0| 4.8$ & $0.8|0.6| 0.4$ \\
\hline $5.6|6.8| 7.7$ & $6.3|7.6| 8.7$ & $12.5 \mid 11.8$ | 13.0 & $0.7|0.8| 1.0$ \\
\hline
\end{tabular}

${ }^{a}$ Field experiments details in the Table 1 and Figure 3a-d. 
wide). In this section, the river is narrower, with very sharp curves and where the movement of the seeds was more influenced by weak winds transverse to the direction of the main flow. During the flood tide, the seed loss was less than c. 5\%, owing to the wider channel $(>250 \mathrm{~m})$ that facilitates dispersal.

\section{DISCUSSION}

Our results represent the first attempt to relate hydrodynamic processes to hydrochory in the lower Amazon. We showed that the net and maximum flow rates of the Maracá River increased from the dry to the rainy season, and that this is accompanied by a greater overall movement of seeds. We further show that potential maximum dispersal distances within one semi-diurnal tidal cycle are 55\% larger in the rainy season when compared with the dry season. Since the time taken for the tide to fall is longer than the time taken for it to rise also increases the chances that seeds will reach the main channel of the Amazon River, thereby increasing the probability that seeds will be dispersed over long distances (Figure 3d, at c. $13 \mathrm{hr}$ ). These results represent average distances moved during just one tidal cycle. However, seeds may well be continually re-dispersed during several tidal cycles, increasing the actual dispersal distance (Cunha et al., 2013; Nilsson et al., 2010).

Our parameterised simulation model can be an important tool to study dynamic processes such as hydrochory. Evidence from subtropical rivers suggests that the peak of tree fruiting in floodplain forests coincides with the period of inundation and that the specific timing of diaspore (seed) release is related to the presence of other dispersal vectors such as fish (Lopez, 2001). Furthermore, the mean species richness and mean number of seeds dispersed have been found to increase with discharge or river water level (Boedeltje et al., 2004). Given the likely crucial role of hydrochory in maintaining diversity in the flooded forests (várzea) of the Amazon (Kubitzki \& Ziburski, 1994; Nilsson et al., 2010), methodological approaches and data such as those presented in this study are essential to help characterise ecosystem processes and to manage these areas for the protection of biodiversity and ecosystem function.

There are logistical complications that limit the potential for experiments in the remote environments of the Amazon, which in turn makes it difficult to obtain data with which to validate model estimates. Furthermore, obtaining fast liquid discharge measurements in large tidal rivers requires sophisticated methodologies, such as ADP, as traditional flow vane approaches are not suitable, especially if the river is very wide (>15 m). Indeed, the technique of acoustic profiling used in this research shows some advantages compared to the traditional methods due to the greater quantity and quality of data, and excellent precision (margin of error $<5 \%$ ) (Ward et al., 2013, 2016). While Stone and Hotchkiss (2007) described how accurate flow measurements in the field are necessary for various applications, including ecological studies and the development of numerical models that represent the flow dynamic, defining the turbulent river flow and associated hydrodynamic behaviour to represent hydrochory is far from straightforward. For example, while some of the seeds released during the experiments (flood/ebb tides at SLS-Down/SLS-UP, c. 5\%-40\% respectively) were stranded in the river margins, in the model, all seeds were assumed to be floating in the river channel during the entire tidal cycle without losses to the margins or bottom of the channel. While this study used $C$. guianensis as a model seed, it is possible to incorporate other species into SisBaHia by changing, for example the timing of seed drop into the river, or seed characteristics such as age, size, weight and buoyancy, or by specifying a settling velocity. As such, this approach is easily adaptable to other species and regions.

\section{5 | CONCLUSION}

This study represents an important advance in the characterisation of seasonal river flow in the tidally influenced Amazon estuary. The results of this study confirm that the period of highest precipitation provides the hydrological conditions most favourable for long-distance seed dispersal by water in the Amazon river-estuary complex. The fact that the time taken for the tide to fall is longer in relation to the time taken for it to rise also favours the arrival of the seeds in the main channel of the River Amazon, thereby increasing the probability of long-distance dispersal events. Spatiotemporal patterns of seed dispersal by water are generally not well known, although their characterisation is crucial for conservation planning due to their influence on gene flow, diversity and ecosystem function. Simulation models are an important and under-used tool for characterisation of dispersal kernels in riverine systems. To the best of our knowledge, this is the first study to attempt to quantify hydrochory in the Amazon river-estuary complex based on river hydrodynamics.

\section{ACKNOWLEDGMENTS}

This study was supported financially by the Conselho Nacional de Desenvolvimento Científico e Tecnológico (CNPq)_Processes 303715/2015-4 and 475614/2012-7, and by projects: Florestam funded by the Empresa Brasileira de Pesquisa Agropecuária (EMBRAPA-Amapá), REMAM2 funded by the Financiadora de Estudos e Projetos (FINEP/CNPq), and CENBAM funded by the Instituto Nacional de Pesquisas da Amazônia (INPA), TROCAS: Net Ecosystem Exchange of Lower Amazon (Fundação de Amparo á Pesquisa de São Paulo: FAPESP no. 2012/51187) and the Environmental Modeling System Laboratory of the Universidade Federal do Amapá (UNIFAP).

\section{REFERENCES}

Abreu, J. C., Guedes, M. C., \& Lira-Guedes, A. C. (2014). Estrutura e distribuição espacial de andirobeiras (Carapa spp.) em floresta de várzea do estuário amazônico. Ciência Florestal, 24, 1007-1016.

Agência Nacional de Águas (2016). Região hidrográfica Amazônica: A maior do mundo em disponibilidade de água. Retrieved from http://www2.a na.gov.br/Paginas/portais/bacias/amazonica.aspx 
Barbedo, J., Miguez, M., van der Horst, D., \& Marins, M. (2014). Enhancing ecosystem services for flood mitigation: A conservation strategy for peri-urban landscapes. Ecology and Society, 19, 54. http://dx.doi. org/10.5751/ES-06482-190254

Bastos, A. (2010). Modelagem de escoamento ambiental como subsídio à gestão de ecossistemas aquáticos no Baixo lgarapé da Fortaleza. Masters thesis, Universidade Federal do Amapá, Macapá, Brazil.

Boedeltje, G., Bakker, J. P., Brinke, A. T., Van Groenendael, J. M., \& Soesbergen, M. (2004). Dispersal phenology of hydrochorous plants in relation to discharge, seed release time and buoyancy of seeds: The flood pulse concept supported. Journal of Ecology, 92, 786-796.

Cain, M. L., Milligan, B. G., \& Strand, A. E. (2000). Long-distance seed dispersal in plant populations. American Journal of Botany, 87, 12171227.

Carthey, A. J. R., Fryirs, K. A., Ralph, T. J., Bu, H., \& Leishman, M. R. (2016). How seed traits predict floating times: A biophysical process model for hydrochorous seed transport behaviour in fluvial systems. Freshwater Biology, 61, 19-31.

Cunha, A. C., Santos, E. W. G., Santos, E. S., Guedes, M. C., Oliveira, G. P., Blanco, C. J. C., \& Rosman, P. C. C. (2013). Importância da hidrodinâmica na dispersão de sementes em sistemas florestais do Baixo Estuário Amazônico. Simpósio Brasil. de Agropecuária Sustentável e Congresso Internacional de Agropecuária Sustentável, Viçosa.

Cunha, C., Scudelari, A., Gonçalves, J., \& Mercuri, E. (2011). Assessment of sanitary sewage pollution in the Paranaguá estuarine complex of Paranaguá, Brazil using environmental modeling. Journal of Coastal Research, 64, 912.

Cunha, C., Scudelari, A., \& Rosman, P. (2015). Using modelling techniques to assess sewage pollution in the Potengi River Estuary, Brazil. WIT Transactions on Ecology and the Environment, 200, 237-248.

Dantas, A. R., Lira-Guedes, A. C., Mustin, K., Aparício, W. C. S., \& Guedes, M. C. (2016). Phenology of the multi-use tree species Carapa guianensis in a floodplain forest of the Amazon Estuary. Acta Botanica Brasilica, 30(4), 618-627.

FEMAR (2013). Catálogo de Estações Maregráficas Brasileiras: Estação Porto de Santana. Retrieved from http://www.fundacaofemar.org.br/ biblioteca/emb/tabelas/019.html

Galo, M. N. (2004). A influência da vazão fluvial sobre a propagação da maré no estuário do Rio Amazonas. Masters thesis, Universidade Federal do Rio de Janeiro, Rio De Janeiro, Brazil.

Howe, H. F., \& Smallwood, J. (1982). Ecology of seed dispersal. Annual Review of Ecology and Systematics, 13, 201-228.

Instituto Brasileiro de Geografia e Estatística (1977). Geografia do Brasil: Região Norte. Rio de Janeiro: Ministério do Planejamento, Desenvolvimento e Gestão.

Instituto Nacional de Meteorologia (2015). Ministério da Agricultura, Pecuária e Abastecimento. Retrieved from http://www.inmet.gov.br

Kenfack, D. A. (2011). Synoptic revision of Carapa (Meliaceae). Harvard Papers in Botany, 16, 171-231.

Kubitzki, K., \& Ziburski, A. (1994). Seed dispersal in flood plain forests of Amazonia. Biotropica, 26, 30-43.

Leite, L., Dias, J., Carvalho, J., \& Klein, A. (2011). Hydrodynamic study of bay beaches-A case study of Itapocorói Bay, Brazil. Journal of Coastal Research, 64, 1086.

Levin, S. A., Muller-Landau, H. C., Nathan, R., \& Chave, J. (2003). The ecology and evolution of seed dispersal: $A$ theoretical perspective. Annual Review of Ecology, Evolution, and Systematics, 34, 575-604.

Lopez, O. R. (2001). Seed flotation and postflooding germination in tropical terra firme and seasonally flood forest species (hydrochory in tropical tree species). Functional Ecology, 15, 763-771.

Mchargue, L. A., \& Hartshorn, G. S. (1983). Seed and seedling ecology of Carapa guianensis. Turrialba, 33(4), 399-404.

Merritt, D. M., \& Wohl, E. E. (2002). Processes governing hydrochory along rivers: Hydraulics, hydrology, and dispersal phenology. Ecological Applications, 12, 1071-1087.
Moegenburg, S. M. (2002). Spatial and temporal variation in hydrochory in Amazonian floodplain forest. Biotropica, 34, 606-612.

Mueller, D. S., Wagner, C. R., Rehmel, M. S., Oberg, K. A., \& Rainville, F. (2009). Measuring discharge with acoustic Doppler current profilers from a moving boat. Reston, Virginia (EUA): US Department of the Interior, US Geological Survey.

Nathan, R., \& Muller-Landau, H. C. (2000). Spatial patterns of seed dispersal, their determinants and consequences for recruitment. Trends in Ecology \& Evolution, 15, 278-285.

National Geospatial-Intelligence Agency (2014). Publication 124, sailing directions (en route): east coast of South America (14th ed.). Retrieved from http://msi.nga.mil/MSISiteContent/StaticFiles/NAV_PUBS/SD/ Pub124/Pub124bk.pdf

Nilsson, C., Brown, R. L., Jansson, R., \& Merritt, D. M. (2010). The role of hydrochory in structuring riparian and wetland vegetation. Biological Reviews, 85, 837-858.

Onset (2016). User Manual. Retrieved from http://www.onsetcomp. com/files/manual_pdfs/12315-G\%20MAN-U20.pdf

Ouborg, N. J., Piquot, Y., \& Van Groenendael, J. M. (1999). Population genetics, molecular markers and the study of dispersal in plants. Journal of Ecology, 87, 551-568.

Prance, G. T. (1979). Notes on the vegetation of Amazonia III. The terminology of Amazonian forest types subject to inundation. Brittonia, 31, 26-38.

Rosman, P. C. C. (2016). Referência técnica do SisBaHiA. Rio de Janeiro: UFRJ-COPPE. Engenharia Costeira \& Oceanográfica.

Salati, E., \& Vose, P. B. (1984). Amazon basin: A system in equilibrium. Science, 225, 129-138.

Santos, E. S. (2012). Modelagem Hidrodinâmica e Qualidade da Água em Região de Pororoca na Foz do Rio Araguari-AP. Masters thesis, Universidade Federal do Amapá, Macapá, Brazil.

Santos, M. L. S., Lima Saraiva, A. L., Pereira, J. A. R., Nogueira, P. F. R., \& Silva, A. C. (2015). Hydrodynamic modeling of a reservoir used to supply water to Belem (Lake Agua Preta, Para, Brazil). Acta Scientiarum. Technology, 37, 353-359.

Scarano, F. R., Pereira, T. S., \& Rõças, G. (2003). Seed germination during floatation and seedling growth of Carapaguianensis, a tree from flood-prone forests of the Amazon. Plant Ecology, 168, 291-296.

Souza, L., Cunha, A., Junior, A. B., \& Pinheiro, L. A. (2011). Estudo do campo de isovelocidades para avaliação do posicionamento de turbinas hidrocinéticas no rio Maracá-AP. Engenharia Ambiental: Pesquisa e Tecnologia, 8, 251-264.

Stone, M. C., \& Hotchkiss, R. H. (2007). Evaluating velocity measurement techniques in shallow streams. Journal of Hydraulic Research, 45, 752762.

Ward, N. D., Bianchi, T. S., Sawakuchi, H. O., Gagne-Maynard, W., Cunha, A., Brito, C. D. C., ... Keil, R. G. (2016). The reactivity of plantderived organic matter and the potential importance of priming effects along the lower Amazon River. Journal of Geophysical Research: Biogeosciences, 121, 1522-1539.

Ward, N. D., Keil, R. G., Medeiros, P. M., Brito, D. C., Cunha, A. C., Dittmar, T., ... Richey, J. E. (2013). Degradation of terrestrially derived macromolecules in the Amazon River. Nature Geoscience, 6, 530-533.

How to cite this article: da Cunha AC, Mustin K, dos Santos ES, et al. Hydrodynamics and seed dispersal in the lower Amazon. Freshwater Biol. 2017;00:1-9. https://doi.org/ 10.1111/fwb.12982 